\title{
ЗНАЧЕННЯ ЕНДОТЕЛІНУ У ПЕРЕБІГУ ПОЗАЛІКАРНЯНОЇ ПНЕВМОНІЇ У ДІТЕЙ
}

\author{
○І. Б. Чорномидз, Т. М. Косовська, В. О. Косовська
}

ДВНЗ «Тернопільський державний медичний університет імені І. Я. Горбачевського МОз Украӥни»

РЕЗЮМЕ. В останні роки все більше уваги приділяють ролі порушень мікроциркуляції та ендотеліальній дисфункції у патогенезі багатьох захворювань, зокрема і пневмонії. Не вивченою на сьогодні $\epsilon$ роль ендотеліну, як маркера ушкодження ендотелію судин, у розвитку пневмонії у дітей.

Мета дослідження - вивчити роль ендотеліну-1 у перебігу позалікарняної пневмонії у дітей та встановити зв'язок рівня цього медіатора у крові з тяжкістю перебігу пневмонії та розвитком ускладнень.

Матеріал і методи. Обстежено 96 дітей віком від 6 до 14 років, хворих на гостру позалікарняну пневмонію різної тяжкості. Рівень ендотеліну-1 у крові визначали імуноферментним методом з використанням набору реактивів «R\&D», США. Дослідження проводили до та після проведеного лікування.

Результати. Встановлено достовірне зростання вмісту ендотеліну-1 у крові дітей, хворих на позалікарняну пневмонію середньої тяжкості, та при тяжкому перебігу захворювання. Рівень цього показника збільшується при зростанні тяжкості патологічного процесу, при цьому рівень ендотеліну перед лікуванням перевищує показники здорових осіб приблизно в 4 рази при пневмонії середньої тяжкості та у 6 разів - при тяжкій. Після лікування у крові утримуються високі показники рівня ендотеліну, що може призвести до порушень мікроциркуляції, гіпоксії та збільшує ризик хронізації патологічного процесу. Встановлено, що високі показники ендотеліну-1 у крові можуть призвести до збільшення ризику розвитку тяжких гнійних ускладнень позалікарняної пневмонії.

Висновки. У дітей, хворих на позалікарняну пневмонію, встановлено зростання у крові рівня ендотеліну-1. При зростанні тяжкості перебігу захворювання пропорційно зростає і рівень ендотеліну у крові. Підвищення рівня ендотеліну-1 у крові може свідчити про ймовірний розвиток тяжких гнійних ускладнень позалікарняної пневмонії. Після лікування позалікарняної пневмонії у дітей залишається підвищений вміст ендотеліну у крові, що може стати причиною хронізації патологічного процесу в легенях.

ключовІ СлОвА: ендотелін-1; позалікарняна пневмонія; ендотелій; діти; розвиток ускладнень.

Вступ. Однією із частих форм ураження органів дихання $\epsilon$ пневмонія, яка і в наш час залишається важливою медико-соціальною проблемою. Пневмонія $\epsilon$ найчастішою причиною смерті дітей внаслідок інфекційних захворювань, яка забирає щороку приблизно 3 млн життів $[1,2]$. Щороку близько 150 мільйонів дітей у світі хворіють на пневмонію. Незважаючи на впровадження у клініку найсучасніших антибактеріальних засобів, смертність від пневмонії залишається досить високою, особливо у дітей раннього віку [1, 3]. Очевидно, однією із причин недостатньої ефективності лікування $\epsilon$ орієнтація на застосування виключно антибактеріальних засобів та нехтування засобами патогенетичної терапії через нез'ясованість окремих ланок патогенезу захворювання [1, 3].

В останні роки все більше уваги приділяють ролі порушень мікроциркуляції та ендотеліальній дисфункції у патогенезі багатьох захворювань, зокрема і пневмонії [4]. Важливе значення при цьому приділяють ендотеліальним медіаторам. Разом із оксидом азоту, ендотелін $\epsilon$ одним із найважливіших регуляторів функціонального стану ендотелію. Він $\epsilon$ найпотужнішим вазоконстриктором в організмі людини $[5,6]$.

Ендотеліни - це група поліпептидів, яка складається із трьох ізомерів (ендотелін-1, ендотелін-2, ендотелін-3). Власне ендотелій судин се- кретує один великий попередник ендотелінів, який під впливом ендотелінперетворювального ферменту перетворюється у три ізомери [5]. Переважна більшість ендотелінперетворювального ферменту міститься в ендотелії судин легень та серця $[5,7]$.

Основний механізм дії ендотелінів полягає у звільненні кальцію, що викликає: стимуляцію всіх фаз гемостазу, починаючи з агрегації тромбоцитів і закінчуючи утворенням червоного тромбу; скорочення і ріст гладких м'язів судин, що призводить до потовщення стінки судин і зменшення їх діаметра, знижує апоптоз клітин [6-8]. Кардіальна дія виражається в позитивному інотропному і батмотропному впливах [9].

Активаторами синтезу ендотеліну $\epsilon$ катехоламіни, ангіотензин II, вазопресин, інсулін, окиснені ЛПнЩ, фактори росту, тромбін, гіпоксія, ішемія та механічне пошкодження ендотелію. Інгібують синтез ЕТ-1 натрійуретичний пептид, ЕТ-3, простагландини E2 і 12, оксид азоту. Легені виділяють до 90 \% ендотелінів [5-8].

Визначається два механізми модуляції судинної відповіді до ендотеліну. По-перше, ендотелій $\epsilon$ анатомічним бар'єром, що обмежує доступ ендотеліну до гладеньких м'язів судин, тому ендотелін викликає спазм судин тільки на ділянках 3 ураженим ендотелієм. По-друге, під впливом ен- 
Огляди літератури, оригінальні дослідження, погляд на проблему, ювілеї

дотеліну ендотеліальні клітини продукують субстанції з вазодилатаційою активністю [10].

Ефекти ендотелінів залежать і від властивостей рецепторів, з якими вони сполучаються. $3^{\prime} є$ днуючись з А-рецепторами, ендотеліни гальмують синтез NO в судинах і викликають їх звуження, а реагуючи з рецепторами В-І викликають розширення судин (гальмують утворення цАМФ і посилюють синтез NO) [5, 7]. Має значення і доза ендотелінів: у фізіологічних умовах ендотеліни утворюються в малих кількостях i, реагуючи з В-1 рецепторами, розширюють судини. Однак, пошкоджений ендотелій синтезує велику кількість ендотелінів, викликаючи вазоконстрикцію через А-рецептори $[5,7]$.

Високі концентрації ендотеліну-1 здатні спричинити бронхоспазм. Разом із стимуляцією затримки рідини в організмі внаслідок інкреції альдостерону, ендотелін сприяє застійним процесам у легенях. Спазм легеневих артерій при цьому сприяє розвитку легеневої гіпертензії $[5,7,11]$.

Роль ендотеліну на сьогоднішній день досліджується в патогенезі артеріальної гіпертензії, атеросклерозу, інфаркту міокарда та інших захворювань серцево-судинної системи $[6,8,9]$. Патогенетичне значення ендотеліну при патології органів дихання досліджується, зокрема, при бронхіальній астмі, хронічних обструктивних захворюваннях легень тощо [9-13].

На сьогоднішній день не вивченою залиша$\epsilon$ ться роль ендотеліну в патогенезі гострої пневмонії у дітей та його роль у розвитку ускладнень.

Метою нашого дослідження було вивчити роль ендотеліну-1 у перебігу позалікарняної пневмонії у дітей та встановити зв'язок рівня цього медіатора у крові з тяжкістю перебігу пневмонії та розвитком ускладнень.

Матеріал і методи дослідження. Дослідження проводили на базі пульмонологічного, хірургічного, діагностичного та поліклінічного відділень Тернопільської обласної дитячої клінічної комунальної лікарні, Тернопільської міської дитячої поліклініки. В основу клінічного дослідження покладено аналіз результатів комплексного обстеження 96 дітей віком від 6 до 14 років, хворих на гостру позалікарняну пневмонію. Контрольну групу склали 32 дитини аналогічного віку без тяжкої соматичної патології та запальних захворювань.

Усі діти, хворі на позалікарняну пневмонію, були поділені на 3 рівні групи по 32 дитини із легким, середньотяжким та тяжким перебігом захворювання. Діти отримували комплекс лікування відповідно до протоколів, затверджених $\mathrm{MO}$ України.

Рівень ендотеліну-1 у крові визначали імуноферментним методом з використанням набору реактивів «R\&D», США. Дослідження проводили до та після проведеного лікування.

Статистичну обробку даних здійснювали шляхом застосування методів дослідження випадкових величин та описової статистики. Визначали середню величину показників (М), середню помилку середньої величини (m). Значення біохімічних показників подавали як $(\mathrm{M} \pm \mathrm{m})$. Вірогідність відхилення двох рядів значень обчислювали з використання t-тесту Стьюдента. Вірогідною вважали відмінність між рядами при $p<0,05$. Для з'ясування впливу непараметричних даних на зміну рівня ендотеліну-1 в крові використовували однофакторний дисперсійний аналіз ANOVA, користуючись комп'ютерними програмами Statistica v 8.0 та Microsoft $\circledast$ Excel 2007 в середовищі Windows XP Profesional SP3.

Результати й обговорення. Отримані дані свідчать, що у дітей, хворих на пневмонію, перед початком лікування спостерігається збільшення рівня ендотеліну-1 у плазмі крові, порівняно із контрольною групою. Зростання рівня цього медіатора $\epsilon$ досить суттєвим і перевищує показники здорових осіб приблизно в 4 рази у групі із пневмонією середньої тяжкості та у 6 разів у групі із тяжким перебігом пневмонії $(p<0,05)$. Лише у групі хворих із легким перебігом пневмонії зростання рівня ендотеліну-1 у крові сягає $10 \%(p>0,05)$ (рис. 1).

Активація синтезу ендотеліну-1, ймовірно, $\epsilon$ відповіддю на пошкодження ендотеліоцитів токсинами при розпалі запального процесу в легенях. Також підвищення цього показника можна пов'язати із компенсаторною відповіддю на гіперпродукцію оксиду азоту при активації iNOS. Внаслідок зниження елімінації ендотеліну при ушкодженні легеневої тканини та інактивації оксиду азоту при його взаємодії із вільними радикалами (утворення пероксинітриту та ін.) виникає дисбаланс між вазоконстрикторами та вазодилататорами у сторону звуження судин. Ці зміни здатні призвести до гіпоксії периферійних тканин, порушення згортання крові і, як наслідок, розвитку ускладнень. Закономірно, що у дітей в групі із легким перебігом пневмонії, у яких запальні явища менш виражені, рівень ендотеліну-1 у крові $є$ мінімальним.

Після лікування у дітей із легким перебігом позалікарняної пневмонії рівень ендотеліну-1 у крові знижувався незначно (на 2,5 \%) і достовірно не відрізнявся від значень здорових осіб ( $>0,05)$. При перебігу пневмонії середньої тяжкості значення цього показника знижується значно помітніше і сягає $(2,40 \pm 0,13)$ пг/мл, що в 2 рази перевищує значення здорових осіб. Після лікування дітей, хворих на тяжку позалікарняну 
Огляди літератури, оригінальні дослідження, погляд на проблему, ювілеї

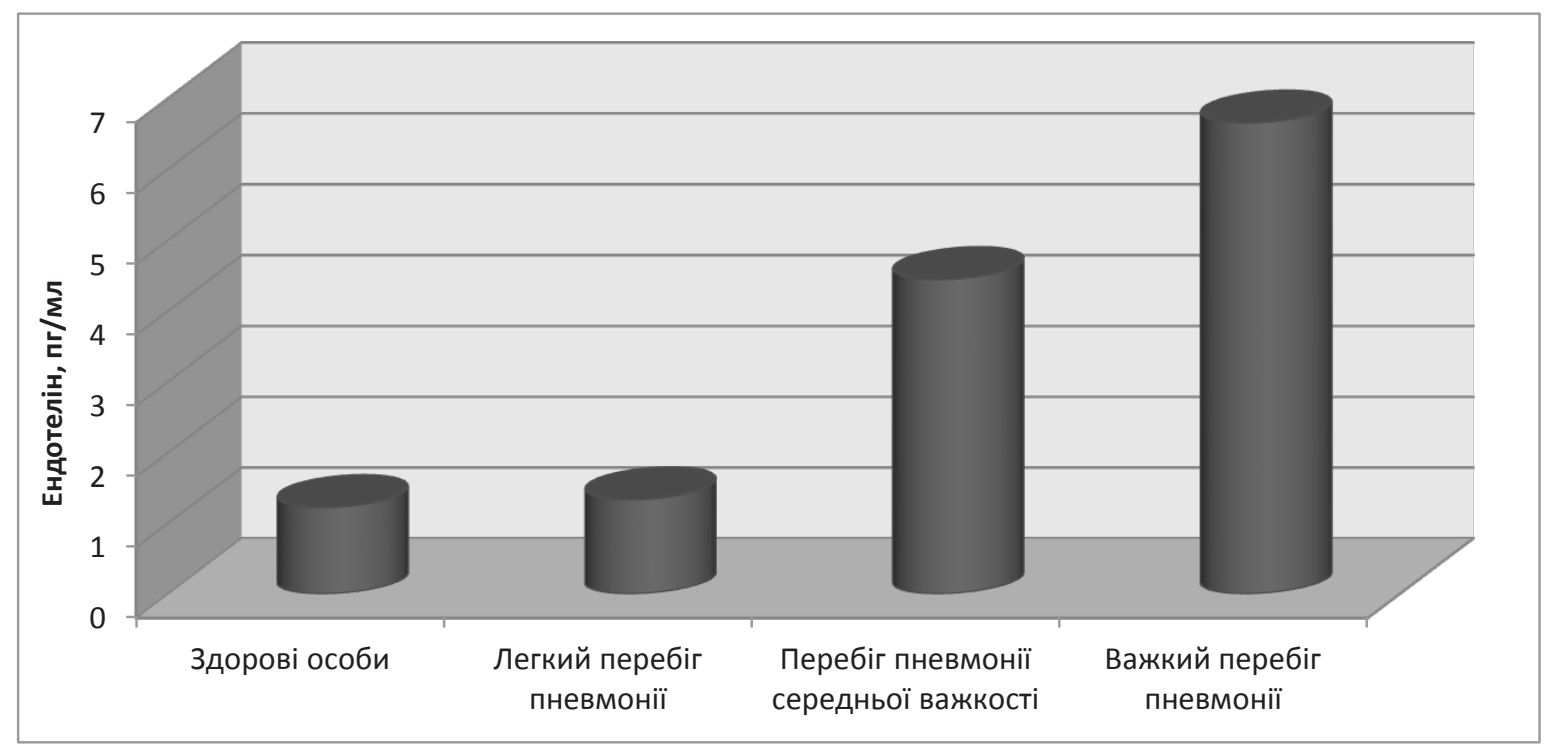

Рис. 1. Рівень ендотеліну-1 при позалікарняній пневмонії у дітей до лікування, пг/мл.

пневмонію, рівень ендотеліну в крові перевищує показники здорових осіб у 3 рази і сягає $(3,66 \pm 0,10)$ пг/мл.

Високий вміст ендотеліну-1 після завершення лікування може призводити до порушень мікроциркуляції як локально, так і на системному рівні, гіпоксії тканин та хронізації запального процесу.
Ми провели аналіз залежності рівня ендотеліну-1 у крові дітей, хворих на позалікарняну пневмонію, на початку лікування, від розвитку ускладнень. Встановлено, що при зростанні рівня ендотеліну-1 у крові зростає й вірогідність розвитку деструктивних ускладнень позалікарняної пневмонії у дітей $(p<0,05)$ (рис. 2).

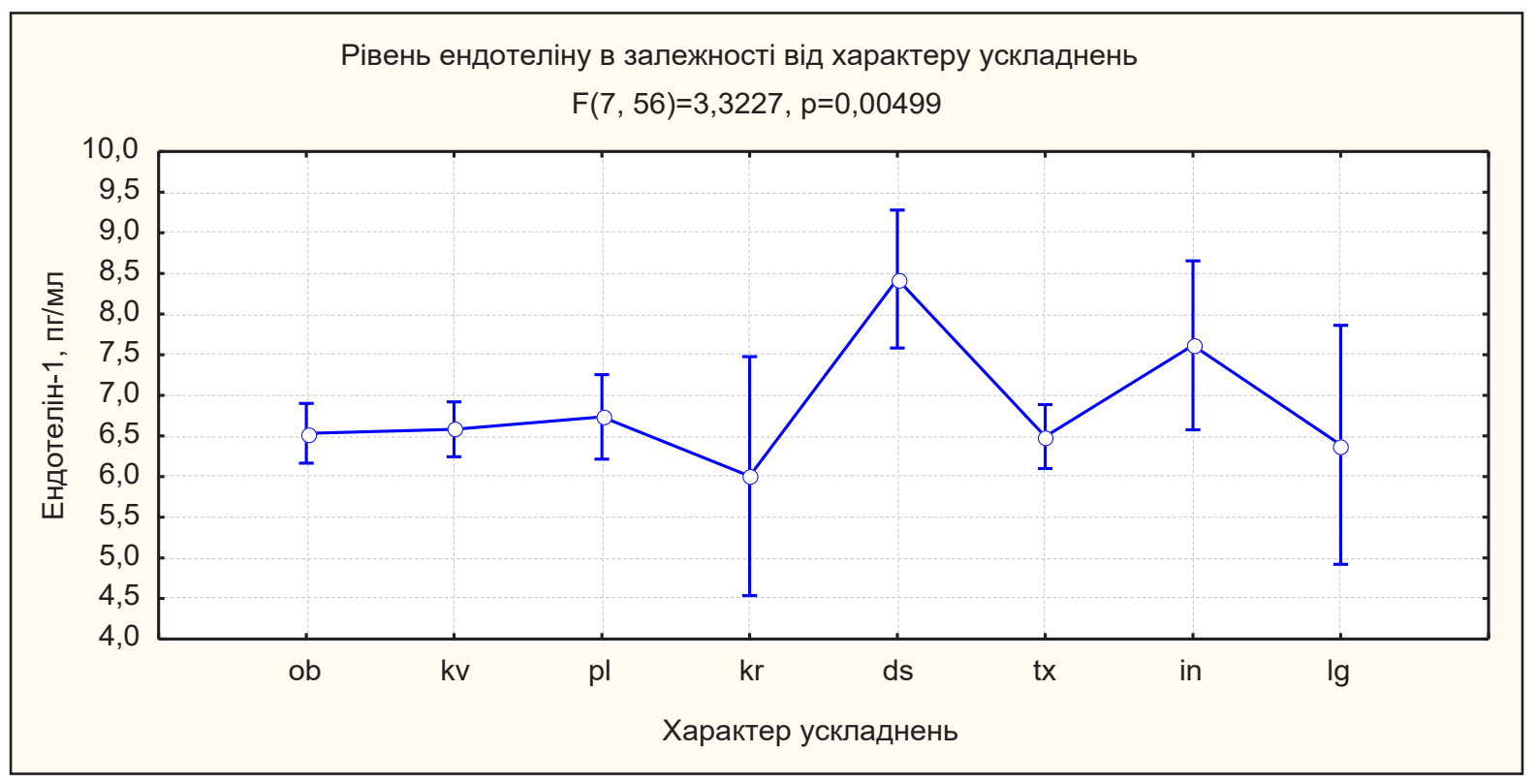

Рис. 2. Рівень ендотеліну-1 у крові дітей, хворих на позалікарняну пневмонію, на початку лікування, залежно від характеру ускладнень (ob - обструктивний синдром; kw - кардіоваскулярний синдром; pl - плеврит; kr - кровохаркання; ds - деструкція; tx - токсикоз; lg - легенева гіпертензія; in - iнші).

Дещо нижчі цифри рівня ендотеліну-1 виявлені у пацієнтів із кровохарканням. Достовірного зв'язку рівня ендотеліну із розвитком інших ускладнень не виявлено. Після лікування достовірної залежності між досліджуваними показниками та характером ускладнень не виявлено. 
Огляди літератури, оригінальні дослідження, погляд на проблему, ювілеї

Висновки. 1. У дітей, хворих на позалікарняну пневмонію, встановлено зростання у крові рівня ендотеліну-1. При збільшенні тяжкості перебігу захворювання пропорційно зростає і рівень ендотеліну у крові. Відповідно, цей показник може бути використаний як маркер тяжкості перебігу пневмонії.

2. Високий вміст ендотеліну у крові може призвести до переважання вазоконстрикторного впливу, порушень мікроциркуляції та розвитку гіпоксії периферійних тканин, що може стати причиною тяжчого перебігу позалікарняної пневмонії.

3. Підвищення рівня ендотеліну-1 у крові може свідчити про ймовірний розвиток тяжких гнійних ускладнень позалікарняної пневмонії.

\section{ЛІТЕРАТУРА}

1. Harris M. British Thoracic Society guidelines for the management of community acquired pneumonia in children: update 2011 / M. Harris, J. Clark, N. Coote [et al.] // Thorax. - 2011. - Vol. 66. - P. 1-23.

2. UNICEF and WHO. Pneumonia: the forgotten killer of children. United Nations Children's Fund, World Health Organization, New York, NY; 2006

3. Montejo Fernández M. Clinical and epidemiological study of community-acquired pneumonia in children aged less than 5 years old / M. Montejo Fernández, C. González Díaz, S. Mintegi Raso, J. Benito Fernández // An. Pediatr. (Barc). - 2005. - Vol. 63, No. 2. - P. 131-136.

4. Федорців О. Є. Стан ендотелію судин у дітей, хворих на гостру позалікарняну пневмонію / О. Є. Федорців, І.Б. Чорномидз // Biomedical and Biosocial Anthropology. - 2009. - № 12. - С. 186-188.

5. Патарая С. А. Биохимия и физиология семейства эндотелинов / С. А. Патарая, А. В. Преображенский, Б. А. Сидоренко // Кардиология. - 2000. - № 6. - С. 76-79.

6. Абидова К. Р. Значение эндотелина-1 в регуляции функций сердечно-сосудистой системы / К. Р. Абидова // Врач. дело. - 1999. - № 7-8. - С. 22-27.

7. Гомазков О. А. Эндотелин в кардиологии: молекулярные, физиологические и патологические аспекты / О. А. Гомазков // Кардиология. - 2001. - № 2. - С. 50-58.

\section{REFERENCES}

1. Harris, M., Clark, J., \& Coote, N. (2011). British Thoracic Society guidelines for the management of community acquired pneumonia in children: update 2011. Thorax, 66, 1-23

2. UNICEF and WHO. (2006). Pneumonia: the forgotten killer of children. United Nations Children's Fund, World Health Organization, New York, NY.

3. Montejo Fernández, M., González Díaz, C., Mintegi Raso, S., Benito Fernández, J. (2005). Clinical and epidemiological study of community-acquired pneumonia in children aged less than 5 years old. An. Pediatr. (Barc), 63 (2), 131-136.
4. Після лікування позалікарняної пневмонії у дітей залишається підвищений вміст ендотеліну у крові, що може стати причиною хронізації патологічного процесу в легенях.

Перспективи подальших досліджень. Використання у комплексній терапії позалікарняної пневмонії у дітей засобів, що здатні впливати на функціональний стан ендотелію судин та запобігати надмірній секреції ендотеліну, могло 6 стати важливою ланкою патогенетичної терапії. Вплив на рівень ендотеліну у крові дав би можливість зменшити тяжкість перебігу пневмонії та запобігти розвитку ускладнень.

8. Визир В. А. Роль эндотелина-1 в прогрессировании сердечной недостаточности / В. А. Визир, А. Е. Березин // Укр. Мед. Часопис. - 2003. - № 3 (35). - С. 5-16.

9. Треумова С. І. Роль вазоконстрикторної функції ендотелію в патогенезі серцево-судинної та бронхолегеневої патології / С. І. Треумова, В.П.Боряк // Вісник проблем біології і медицини. - 2014. - Вип. 1 (106). C. 31-35.

10. Леженко Г. О. Стан функції ендотелію у дітей із хронічними та рецидивними захворюваннями бронхолегеневої системи / Г. О. Леженко, О. Є. Пашкова // Буковинський медичний вісник. - 2013.- Т. 17, № 3 (67). C. 48-52.

11. Юлдашева И. А. Состояние эндотелия сосудов у больных бронхиальной астмой / И. А. Юлдашева // Клин. мед. - 2004. - № 5. - С. 36-38.

12. Федорців О. $€$. Діагностичне значення визначення маркерів ендотеліальної дисфункції в перебігу гострої позалікарняної пневмонії у дітей / О. Є. Федорців, І. Б. Чорномидз // Современная педиатрия. - 2011. № 1 (35). - С. 127-129.

13. Показатели функции эндотелия у больных ХОЗЛ разной степени тяжести / В. И. Блажко, Л. С. Воейкова, Е. О. Крахмалова, И. В. Талалай // Український пульмонологічний журнал. - 2005. - № 4. - С. 44-47. 
Огляди літератури, оригінальні дослідження, погляд на проблему, ювілеї

lar functions]. Vrachebnoe delo - Doctor's Business, 7-8, 22-27 [in Russian].

7. Gomazkov, O.A. (2001). Endotelin v kardiologii: molekulyarnye, fiziologicheskie i patologicheskie aspekty [Endothelin in cardiology: molecular, physiological and pathological aspects]. Kardiologiya - Cardiology, 2, 50-58 [in Russian].

8. Vizir, V.A., \& Berezin, A.E. (2003). Rol endotelina-1 v progressirovanii serdechnoy nedostatochnosti [The role of endothelin-1 in the progression of heart failure]. Ukrainskyi medychnyi chasopys - Ukrainian Medical Journal, 3 (35), 5-16 [in Russian].

9. Treumova, S.I., \& Boriak, V.P. (2014). Rol vazokonstryktornoi funktsii endoteliiu $v$ patohenezi sertsevo-sudynnoi ta bronkholehenevoi patolohii [The role of vasoconstrictor endothelium function in pathogenesis of cardiovascular and bronchopulmonary pathology]. Visnyk problem biolohii $i$ medytsyny - Journal of Problems of Biology and Medicine, 1 (106), 31-35 [in Ukrainian].

10. Lezhenko, H.O., Pashkova, O.le. (2013). Stan funktsii endoteliiu u ditei iz khronichnymy ta retsydyvnymy zakhvoriuvanniamy bronkholehenevoi systemy [Status of endothelial function in children with chronic and recurrent diseases of the bronchopulmonary system]. Bukovynskyi medychnyi visnyk - Bukovyna Medical Journal, 3 (67), 48-52 [in Ukrainian].

11. Yuldasheva, I.A. (2004). Sostoyanie endoteliya sosudov u bolnykh bronkhialnoy astmoy [The state of the vascular endothelium in patients with bronchial asthma]. Klinicheskaya meditsina - Clinical Medicine, 5, 36-38 [in Russian].

12. Fedortsiv, O.le., \& Chornomydz, I.B. (2011). Diahnostychne znachennia vyznachennia markeriv endotelialnoi dysfunktsii v perebihu hostroi pozalikarnianoi pnevmonii u ditei [Diagnostic value of determination of markers of endothelial dysfunction in the course of acute communityacquired pneumonia in children]. Sovremennaya pediatriyaModern Pediatrics, 1 (35), 127-129 [in Ukrainian].

13. Efimov, V.V., Blazhko, V.I., Voeykova, L.S., Krahmalova, E.O., Talalay, I.V., \& Bondar, T.N. (2005). Pokazateli funktsii endoteliya u bolnykh KhOZL raznoy stepeni tyazhesti [Endothelial function in patients with COPD of varying severity]. Ukrainskyi pulmonolohichnyi zhurnal - Ukrainian Pulmonological Journal, 4, 44-47 [in Russian].

\section{ЗНАЧЕНИЕ ЭНДОТЕЛИНА В ТЕЧЕНИИ ВНЕБОЛЬНИЧНОЙ ПНЕВМОНИИ У ДЕТЕЙ ОИ. Б. Чорномидз, Т. М. Косовская, В. А. Косовская \\ ГВУз «Тернопольский государственный медицинский университет имени И. Я. Горбачевского МОЗ Украины»}

РЕЗЮМЕ. В последние годы все больше внимания уделяют роли нарушений микроциркуляции и эндотелиальной дисфункции в патогенезе многих заболеваний, в том числе пневмонии. Не изучена сегодня роль эндотелина, как маркера повреждения эндотелия сосудов, в развитии пневмонии у детей.

Цель исследования - изучить роль эндотелина-1 в ходе внебольничной пневмонии у детей и установить связь уровня этого медиатора в крови с тяжестью течения пневмонии и развитием осложнений.

Материал и методы. Обследовано 96 детей в возрасте от 6 до 14 лет, больных острой внебольничной пневмонией разной тяжести. Уровень эндотелина-1 в крови определяли иммуноферментным методом с использованием набора реактивов «R\&D», США. Исследование проводили до и после проведенного лечения.

Результаты. Установлено достоверное повышение содержания эндотелина-1 в крови детей, больных внебольничной пневмонией средней тяжести, и при тяжелом течении заболевания. Уровень этого показателя увеличивается при росте тяжести патологического процесса, при этом уровень эндотелина перед лечением превышает показатели здоровых лиц примерно в 4 раза при пневмонии средней тяжести и в 6 раз - при тяжелом течении пневмонии. После лечения в крови содержатся высокие показатели уровня эндотелина, что может привести к нарушениям микроциркуляции, гипоксии и увеличивает риск хронизации патологического процесса. Установлено, что высокие показатели эндотелина-1 в крови могут привести к увеличению риска развития тяжелых гнойных осложнений внебольничной пневмонии.

Выводы. У детей, больных внебольничной пневмонией, установлен рост в крови уровня эндотелина-1. При росте тяжести течения заболевания пропорционально растет и уровень эндотелина в крови. Повышение уровня эндотелина-1 в крови может свидетельствовать о вероятном развитии тяжелых гнойных осложнений внебольничной пневмонии. После лечения внебольничной пневмонии у детей остается повышенное содержание эндотелина в крови, что может стать причиной хронизации патологического процесса в легких.

КЛЮЧЕВЫЕ СЛОВА: эндотелин-1; внебольничная пневмония; эндотелий; дети; развитие осложнений. 


\section{THE MEANING OF ENDOTHELIN IN THE CURRENT OF COMMUNITY-ACQUIRED PNEUMONIA IN CHILDREN}

\section{OI. B. Chornomydz, T. M. Kosovska, V. O. Kosovska}

\section{Horbachevsky Ternopil State Medical University}

SUMMARY. Introduction. In recent years, more and more attention has been paid to the role of microcirculation and endothelial dysfunction in the pathogenesis of many diseases, including pneumonia. Until now, the role of endothelin, as a marker of vascular endothelial damage, in the development of pneumonia in children, has not been studied.

The aim of the study - to learn the role of endothelin-1 in the course of community-acquired pneumonia in children and to establish the relationship between the level of this mediator in the blood with the severity of the course of pneumonia and the development of complications.

Material and Methods. 96 children aged 6 to 14 years old, patients with acute pancreatic pneumonia with different course of gravity were examined. The level of endothelin-1 in the blood was determined by the immuno-enzymatic method using a set of reagents "R \& D", USA. Studies were conducted before and after treatment.

Results. There is a significant increase in the content of endothelin-1 in the blood of children suffering from generalized pneumonia of moderate severity and severe illness. The level of this indicator increases with the increase in the severity of the pathological process, with the level of endothelin before treatment exceeds the indexes of healthy subjects approximately 4 times in the group with the course of pneumonia of moderate severity and 6 times in the group with severe pneumonia. After treatment in the blood, high levels of endothelin levels are maintained, which can lead to microcirculatory disorders, hypoxia and increases the risk of chronizing the pathological process. It has been established that high endothelin-1 indices in the blood may increase the risk of severe purulent complications of community-acquired pneumonia.

Conclusion. In children suffering from community-acquired pneumonia, an increase in blood endothelin-1 levels has been observed. With an increase in the severity of the disease, the level of endothelin in the blood increases proportionally. Increasing the level of endothelin-1 in the blood may indicate a possible development of severe purulent complications of community-acquired pneumonia. After treatment of community-acquired pneumonia in children, high levels of endothelin in the blood remain in the blood, which can cause a chronic pathological process in the lungs.

KEY WORDS: endothelin-1; community-acquired pneumonia; endothelium; children; development of complications.

Отримано 12.02.2018 